\title{
Numb Chin Syndrome with Four Fulminant Attacks in 16 Years
}

Keywords: Numb chin syndrome; Mental neuropathy; Lip numbness; Long-term follow-up; Benign

\begin{abstract}
We present a case report of an otherwise healthy 68-year-old man with a 16-year follow-up of recurrent sudden and severe attacks of painful but benign numb chin syndrome (NCS).

The patient presented with only one subjective finding: recurrent mental nerve neuropathy, a periodic, localized, atypical facial pain continuing up to 2 weeks at a time. Undergoing tests on an outpatient basis, a complete lab work-up including dental examination and laboratory tests, electroencephalogram, chest x-ray, abdomina ultrasonography, head and neck magnetic resonance imaging and computed tomography were done.

All examinations and test results were within normal limits and with no remarkable findings in 16 years of follow-up. After family, social, surgical, medical, dental, and psychological histories, with appropriate and careful clinical work-ups, no definitive diagnoses, other than NCS, could be made. An extensive literature search in the PubMed interface using the key words, "numb chin syndrome," "mental neuropathy," and "mental nerve numbness," revealed 152 articles reporting 576 patients. As reported, NCS can be benign or a precursor of certain cancers, leukemia, other morbidity, and mortality. Though inconveniencing and embarrassing, painful and extremely worrying during the periods of infliction, the present case of NCS has been benign for 16 years.
\end{abstract}

\section{Abbreviations}

ALL: Acute Lymphoblastic Leukemia; CT: Computed Tomography; EEG: Electroencephalogram; MRI: Magnetic Resonance Imaging; NCS: Numb Chin Syndrome

\section{Introduction}

Numb chin syndrome (NCS) is also called, "mental nerve neuropathy," and is defined as a sensory neuropathy, characterized, in some cases, by pain and, in all cases, by numbness (hypoesthesia, paresthesia, dysesthesia, and anesthesia) of the unilateral or bilateral chin and lower lip within the mental or inferior alveolar nerve distribution. In 1932, Dandy first saw blood vessels on the trigeminal nerve in a patient presenting with hemifacial paralysis of the chin [1]. NCS could be a precursor of a systemic malignancy, neoplastic disease, or an as yet undiagnosed cancer [1-30]. The presenting symptom of numb chin, with or without comorbid lower lip anesthesia, is more often associated with cancer, either as the first symptom or manifesting during the outcome, than with benign diseases [31,32].

We present the first report documenting the benign, long-term, 16 -year outcome of NCS. The aim of this study was to elucidate the ramifications of the possible prognoses of patients diagnosed with pernicious NCS in order to clarify some of the new science couching this neuropathy.

The patient's informed consent was obtained for all the procedures and the reporting thereof in this study.
Journal of

Syndromes

\section{Robert E. Brandt ${ }^{1-3^{*}}$, Akihiro Takeuchi ${ }^{2}$ and Toshikazu Hirayama ${ }^{3}$}

${ }^{\prime}$ MedEd Japan, Tokyo, Japan

${ }^{2}$ Department of Medical Informatics, Kitasato University School of

Medicine, Kanagawa, Japan

${ }^{3}$ Department of Neurology, St. Marianna University School of

Medicine, Kanagawa, Japan

\section{*Address for Correspondence}

Robert E. Brandt, MedEd Japan, 3-2-12 Eifuku, Suginami, Tokyo 1680064, Japan, Tel: +81-3-5930-4568; Fax: +81-42-778-9176; E-mail:

robert_e_brandt@hotmail.com

Submission: 26 June, 2018

Accepted: 31 July, 2018

Published: 10 August, 2018

Copyright: @ 2018 Brandt RE, et al. This is an open access article distributed under the Creative Commons Attribution License, which permits unrestricted use, distribution, and reproduction in any medium, provided the original work is properly cited.

\section{Case Report}

The first NCS attack of this patient occurred at the age of 52 years old with only the presenting symptoms of dysesthesia and a thickening sensation of the right lower lip and chin, local fever, and slight pain. The patient also complained of insomnia, anxiety, and depression during the episode. Examination revealed local swelling, redness and a thickening sensation of the lower lip and chin, and lower anterior gingiva. The symptoms occurred synchronously in bouts of from 3 to 5 days for 2 weeks, after which, all the symptoms resolved spontaneously. However, to rule out a pernicious outcome, complete lab work-ups, including blood and dental laboratory tests, head and neck MRI and CT, electroencephalogram (EEG), chest $\mathrm{x}$-ray, abdominal ultrasonography, were done. All the exam results came back within normal limits, without any remarkable findings. Possible dental problems, such as tooth extraction, trauma, abscess, or osteomyelitis, were all ruled out by thorough evaluation by a 20 year veteran, expert dentist.

He has been physically active and plays tennis at least once a week, never smoked cigarettes but enjoys a glass of wine with dinner. His annual physical health check-ups for the past 30 years have revealed normal results other than stage-2 hypertension which is controlled with medication.

After taking exhaustive family, social, medical, dental, and psychological histories, appropriate and careful clinical work-ups, no definitive diagnosis other than NCS could be made. The symptoms inexplicably resolved spontaneously.

Similar fulminant attacks with the same annoying, awkward, and worrying symptoms occurred at 4-, 3-, and 6-year intervals at the ages of 56, 59, and 65 years old, respectively. Subjective symptoms and findings on attacks were recurrent mental nerve neuropathy, a non-necrotizing symptom of a localized, dysesthesia, atypical facial pain in the right lower lip and chin, and general dullness in the jawbone. Again, at each episode, these symptoms caused insomnia, anxiety, and depression. Although complete lab work-ups, head and 
neck MRI and CT, etc. were repeatedly done, all results were within normal limits and without any remarkable findings. As with the three previous episodes, all the symptoms resolved spontaneously without medical intervention.

The symptoms did not recur in 3 years of follow-up. At the final follow-up examination, at 66 years of age, which consisted of EEG, electromyography, an additional CT and MRI, which was 14 years after the first attack, all were again within normal limits. There was no disclosure of an underlying malignancy, neoplasm, or systemic disease. Although painful and an inconvenience during the periods of infliction, the present case has been benign for 16 years to date, at 68 years of age.

\section{Discussion}

In the last 55 years, 576 patients, reported in more than 100 journals worldwide, comprised our examination of the literature with the PubMed interface using the key words, "numb chin syndrome," "mental neuropathy," and "mental nerve numbness". Our search revealed that of these 576 patients from 19 countries, 137 cases were benign, while alarmingly as many as 439 were malignancies including 11 deaths. Key data were extrapolated and compiled, from this sizable patient population, revealing broad generalizations.

Although relatively rare signs and symptoms, when they do present, they are known collectively as numb chin, and are most often a prodromal sign of a serious malady, as in the 439 cases $(76 \%)$ in the present review. Numb chin turned out to be the prodromal sign and was the initial manifestation of acute lymphoblastic leukemia (ALL) of the B-cell type, Burkitt's-type ALL, other types of leukemia, malignant lymphoma, breast cancer, prostate cancer, other types of cancers, metastatic, and systemic diseases, and even HIV/AIDS [3,7,12,14,17-23,25,28,30-47]. Henny C et al. cautioned, although benign in appearance, NCS is most often associated with visceral neoplasia or malignant hemopathy and a factor of poor prognosis [48]. Massey EW et al. pointed out a nontraumatic mental neuropathy should initiate a search for cancer [12]. Laurencet FM et al. reported survival after diagnosis is generally less than 1 year. The appearance of a mental nerve neuropathy should never be considered as a 'banal' symptom, and investigations to detect a possible cancer should be mandatory [30].

On the other hand, among the 576 cases reviewed plus the case presented in this study, there were 138 benign cases (24\%). Baron JC observed that at variance with classical notions, the outlook of NCS is occasionally benign [49]. While those benign case reports described short-term states, among them there were no reports of any cases involving recurrent attacks or any long-term follow-up studies, as is the case with the patient in the present report. Fortunately, however, for this patient, the painful recurrences of numb chin will remain, for now at least, inexplicably diagnosed as benign. Though inconveniencing and embarrassing, painful and extremely worrying during the periods of infliction, the present case of NCS has been benign for 16 years.

\section{Author Contributions}

Mr. Robert E. Brandt was responsible for the study concept and design, analysis and interpretation of data, and critical revision of the manuscript for important intellectual content and final approval. Dr. Akihiro Takeuchi, analysis and interpretation of data, and of the manuscript for important intellectual content. Dr. Toshikazu Hirayama, acquisition of data, final approval of the manuscript for important intellectual content.

\section{Ethical Standards}

The present work was validated by the Kitasato University Medical Ethics Organization, Kanagawa, Japan, registered as No. B17-284.

\section{References}

1. Calverley JR, Mohnac AM (1963) Syndrome of the numb chin. Arch Intern Med 112: 819-821.

2. Ju DM (1965) Localized anesthesia of the mental nerve. A significant sign of cancer of the mandible. Am J Surg 110: 573-579.

3. Nobler MP (1969) Mental nerve palsy in malignant lymphoma. Cancer 24: 122-127.

4. Thrush DC, Small M (1970) How benign a symptom is facial numbness? Lancet 2: 851-854.

5. Simpson JF (1970) Numb-chin syndrome. Lancet 2: 1366.

6. Konotey-Ahulu FI (1972) Mental-nerve neuropathy: a complication of sicklecell crisis. Lancet 2: 388.

7. Lesnick JA, Zallen RD (1999) Numb chin syndrome secondary to metastatic breast disease. J Colo Dent Assoc 78: 11-14

8. Roistacher SL (1973) Numbness--a significant finding. Oral Surg Oral Med Oral Pathol 36: 22-27.

9. Horowitz SH (1974) Isolated facial numbness. Clinical significance and relation to trigeminal neuropathy. Ann Intern Med 80: 49-53.

10. Rowe WE, Cohen G, Scopp I (1974) Numb-chin syndrome--mandibular metastasis of a reticulum-cell sarcoma. J Oral Med 29: 102-104.

11. Curry JT, Zallen RD (1977) Numb-chin syndrome secondary to a spontaneous hemorrhage into a mandibular cyst: report of case. J Am Dent Assoc 94: 116119.

12. Massey EW, Moore J, Schold SC Jr (1981) Mental neuropathy from systemic cancer. Neurology 31: 1277-1281.

13. Rostein I, Galili D, Or R (1988) Endodontic therapy for mental nerve neuropathy in systemic cancer patients. J Endod 14: 568-570.

14. Marsot-Dupuch K, Matozza F, Firat MM, lyriboz AT, Chabolle F, et al. (1990) Mandibular nerve: MR versus CT about 10 proved unusual tumors. Neuroradiology 32: 492-496.

15. Loughner BA, Larkin LH, Mahan PE (1990) Nerve entrapment in the lateral pterygoid muscle. Oral Surg Oral Med Oral Pathol 69: 299-306.

16. Furukawa T (1990) Numb chin syndrome in the elderly. J Neurol Neurosurg Psychiatry 53: 173.

17. Gaver A, Polliack G, Pilo R, Hertz M, Kitai E (2002) Orofacial pain and numb chin syndrome as the presenting symptoms of a metastatic prostate cancer. J Postgrad Med 48: 283-284.

18. Baskaran RK, Krishnamoorthy, Smith M (2006) Numb Chin Syndrome--a reflection of systemic malignancy. World J Surg Oncol 4: 52.

19. Sanchis JM, Bagan JV, Murillo J, Diaz JM, Poveda R, et al. (2008) Mental neuropathy as a manifestation associated with malignant processes: its significance in relation to patient survival. J Oral Maxillofac Surg 66: 995-998.

20. Divya KS, Moran NA, Atkin PA (2010) Numb chin syndrome: a case series and discussion. Br Dent J 208: 157-160.

21. Ryba F, Rice S, Hutchison IL (2010) Numb chin syndrome: an ominous 
clinical sign. Br Dent J 208: 283-285.

22. Lata J, Kumar $P$ (2010) Numb chin syndrome: a case report and review of the literature. Indian J Dent Res 21: 135-137.

23. Kulisevsky J, Roig C, Rovira A, Escartin AE (1986) Paraneoplastic thrombosis of the upper longitudinal sinus, chronic disseminated intravascular coagulation and mental neuropathy in a female patient with carcinoma of the breast. Neurologia 1: 45-47.

24. Furukawa T (1988) Charles Bell's description of numb chin syndrome. Neurology 38: 331.

25. Bruyn RP, Boogerd W (1991) The numb chin. Clin Neurol Neurosurg 93 187-193.

26. Ojanguren JM, Garcia-Monco C, Capelastegui A, Matinez C, Atutxa K, et al. (1999) Numb chin syndrome in 4 patients with hematologic malignancies. Haematologica 84: 952-953.

27. Maillefert JF, Gazet-Maillefert MP, Tavernier C, Farge P (2000) Numb chin syndrome. Joint Bone Spine 67: 86-93.

28. Sierra-Hidalgo F, de Pablo-Fernandez E, Correas-Callero E, VillarejoGalende A (2009) Numb chin syndrome caused by biphosphonates-induced osteonecrosis of the jaw. Rev Neurol 49: 190-192.

29. Ohno T, Yasuda Y, Furukawa H (1994) Acute monoblastic leukemia (M5a) presenting numb chin syndrome. Am J Hematol 45: 352.

30. Laurencet FM, Anchisi S, Tullen E, Dietrich PY (2000) Mental neuropathy: report of five cases and review of the literature. Crit Rev Oncol Hematol 34: 71-79.

31. Haytac MC, Antmen B, Dogan MC, Sasmaz I (2003) Severe alveolar bone loss and gingival hyperplasia as initial manifestation of Burkitt cell type acute lymphoblastic leukemia. J Periodontol 74: 547-551.

32. Kraigher-Krainer E, Lackner H, Sovinz P, Schwinger W, Benesch M, et al (2008) Numb chin syndrome as initial manifestation in a child with acute lymphoblastic leukemia. Pediatr Blood Cancer 51: 426-428.

33. De Pena CA, Lee YY, Van Tassel P (1989) Lymphomatous involvement of the trigeminal nerve and Meckel cave: CT and MR appearance. AJNR Am J Neuroradiol 10 (5 Suppl): S15-S17.

34. Peñarrocha Diago M, Bagán Sebastián JV, Alfaro Giner A, Escrig Orenga V (1990) Mental nerve neuropathy in systemic cancer. Report of three cases. Oral Surg Oral Med Oral Pathol 69: 48-51.

35. Sebor RJ (1990) Numb chin syndrome: a case report. Compendium 11: 620625 .
36. Turner-lannacci A, Mozaffari E, Stoopler ET (2003) Mental nerve neuropathy: case report and review. CJEM 5: 259-262.

37. Seixas DV, Lobo AL, Farinha NJ, Cavadas L, Campos MM, et al. (2006) Burkitt leukemia with numb chin syndrome and cavernous sinus involvement. Eur J Paediatr Neurol 10: 145-147.

38. Sasaki M, Yamazaki H, Aoki T, Ota Y, Sekiya R, et al. (2011) Bilateral numb chin syndrome leading to a diagnosis of Burkitt's cell acute lymphocytic leukemia: a case report and literature review. Oral Surg Oral Med Oral Pathol Oral Radiol Endod 111: e11-e16.

39. Hiraki A, Nakamura S, Abe K, Takenoshita Y, Horinouchi Y, et al. (1997) Numb chin syndrome as an initial symptom of acute lymphocytic leukemia: report of three cases. Oral Surg Oral Med Oral Pathol Oral Radiol Endod 83: $555-561$.

40. Liapis K, Apostolidis I, Karmiris T, Harhalakis N (2010) Numb chin syndrome as the initial manifestation of acute megakaryoblastic leukemia. Leuk Lymphoma 51: 2310-2311.

41. Sweet JM (2004) The numb chin syndrome: a critical sign for primary care physicians. Arch Intern Med 164: 1347-1348.

42. Vigano P, Picozzi SC, Giuberti A, Casu M. Maganini V, et al. (2007) Numb chin syndrome: the presenting symptom of a metastatic prostate carcinoma. Arch Ital Urol Androl 79: 155-157.

43. Lopez-Jornet $P$ (2007) Mental nerve neuropathy as initial symptom of cancer. N Y State Dent J 73: 36-37.

44. Smith SF, Blackman G, Hopper C (2008) Numb chin syndrome: a nonmetastatic neurological manifestation of malignancy. Oral Surg Oral Med Oral Pathol Oral Radiol Endod 105: e53-e56.

45. Requena A, Riera-Mestre A, Formiga F, Vidaller A, Pujol R (2008) Metastatic prostate carcinoma presenting as numb chin syndrome in elderly people. $J$ Am Geriatr Soc 56: 581-582.

46. Shah D, Shetty S, MacBean AD, Olley SF (2010) Numb chin syndrome: a metastatic deposit in the mandible. Dent Update 37: 244-246.

47. Lossos A, Siegal T (1994) Case 27-1994: the numb chin syndrome. N Engl J Med 331: 1460.

48. Henny C, Kuntzer T, Regli F (1992) Chin neuropathy of neoplastic origin. Schweiz Med Wochenschr 122: 424-427.

49. Baron JC (1995) Benign neuropathy of the chin. Rev Neurol (Paris) 151: $284-$ 285. 